\title{
THE WORLD OF JOURNALISM - THE WORLD OF PUBLIC RELATIONS ASSESSMENT OF CHANGES IN RELATIONS BETWEEN JOURNALISTS AND PR MANAGERS IN POLAND
}

\author{
Stawomir Gawroński?
}

\begin{abstract}
The paper presents a comparative look at the results of similar studies relating to the diagnosis of cooperation between the journalists and representatives of the PR industry in Poland. Comparable subjects, arising from the similarity of used research tools, as well as comparable attempts of the research on both environments provide good opportunities of drawing overlapping conclusions from the two research projects. Although standardization of the cooperation between journalists and PR professionals is very difficult and its description is limited by a number of variables and differentiating factors, comparing both studies makes it possible to draw conclusions about some changes or elements that have remained unchanged in relations PR managers - journalists in Poland over the last 71 years.
\end{abstract}

Keywords: public relations, journalism, mass media, media relations.

\section{Introduction}

Although the cooperation between journalists and managers should be based on partnership and should be balanced between the importance of both of these professions, it is usually dominated by journalists since measurable final product of this cooperation, i.e. news or messages published in the media depend on them. In spite of the fact that journalists and public relations specialists are dependent on each other, the observation of real relations between the representatives of these two groups shows a higher and stronger position of journalists, which results from the lack of symmetry between the importance of both of these environments indicating a higher position of mass media representatives. Practice shows that public relations specialists and journalists quite often adopt completely opposite attitudes - while the first ones look forward to promoting the image of their company, the latter try to defend the independence 
of the media and resist any kind of influence or pressure concerning the content of their message to be published in the media. These relations are therefore advantageous for both sides on the one hand, but very difficult and generating conflicts, on the other.

\section{Interactions - the foundation of good relations}

Two elements are, in my view, the key to a good cooperation between representatives of both professions mentioned above. Firstly, understanding common benefits, which can be brought by professional cooperation in the field of media relations. Such professionalism ought to consist in understanding the needs of the other side and in taking into consideration the limitations imposed by the specificity of both professions. There is very often too little understanding, and particular interests prevail over the reliability of mutual cooperation. If we analyze all the similarities and differences between journalism and public relations, we will notice a clear identity of ethical principles [Dobek-Ostrowska et al, 2013], which can be seen in the content of ethical codes that both professions have worked out over the years of their evolution and mutual cooperation.

There is no doubt that the relationship between journalists and PR specialists has been changing as a result of not only the changes in the way new communication tools are used, but also as a result of the functioning of mass media themselves, a changing profile of media recipients and many other factors. One reason for the attempt of analyzing the tendencies and possible changes in the relations between journalists and PR managers were the results of the latest research "From Information to Interaction. The Usefulness of Press News in Relations PR Specialist - Journalist" carried out by Prowly Agency at the end of 2015 . $^{2}$ The study was based on a sample that was similar to the samples the author had used in his own research on the same subject ${ }^{3}$. These similarities make it interesting to look for relationships, analogies, tendencies and symptoms of the changes in relations between journalists and PR-managers in Poland over the last years.

One of the basic assumptions in building a model of cooperation between journalists and public relations specialists is the rule of partnership in their relations. This partnership stems from a specific identity of interests, which is the result of mutual benefits gained by both sides of the communication process through maintaining appropriate relationships and maintaining certain standards of cooperation. The second assumption is the fact that, in some cases, the partnership in the process of media relations is sometimes quite limited and journalists are treated as "consumers" of the information created and supplied by PR managers who pay a lot of attention to how their message is "distributed" by mass media. In such cases, customer focus involves the subordination of certain behaviors of PR professionals to the needs of journalists.

The comparison of the opinions expressed by representatives of both environments must therefore be correlated with a fairly flexible approach to determine whose opinions on a problem are more relevant and which party respects the expectations of the other.

Nevertheless, it is difficult to range all particular cases of media relations in one single standard. One should also remember that PR techniques and practices seldom fit into any standards. What is more, some PR specialists claim that an effective manager is one who sneaks away from classical rules of public relations [Szczepanik, Krzyżanowska, 2003].

PR specialists can never be sure what they are going to do tomorrow, how they will

\footnotetext{
$2 \quad$ The study included 203 journalists and 205 representatives of the PR industry. The report is available in electronic version at: ebook.prowly.com (dated 24 April 2016).

The study "Współpraca komunikacyjna dziennikarzy i specjalistów PR w Polsce" was realized in 2004 on a sample of 257 PR managers and 218 journalists from all the country.
} 
behave in a specific situation or how they will react. PR activities have an unpredictable nature, which makes PR professionals react in a non-specific way. In addition, all standard, routine PR procedures may stop working with time and may not bring expected results they had brought before. In spite of this, the analysis of the empirical data lets us create a set of rules for the cooperation between PR professionals and journalists, which is universal to a certain extent. Some elements of the proposed model of cooperation between journalists and PR managers include problems connected with a preferred model of communication between the two groups, frequency of mutual contacts and their purpose. They also include universal tools of media relations, expectations about new communication tools and aspects of ethical issues in mutual relations between journalists and PR professionals.

\section{Interactions yesterday}

As a result of research carried out in 2004 it could be noted that the expectations of journalists in relation to PR professionals follow a specific pattern of behavior on the basis of which it was possible to formulate a set of qualities and conditions that make a desired and expected profile of a PR manager. This profile, based on a quantitative analysis of the expectations of the examined environment of journalists are as follows [Gawroński, 2005, p. 277-279]:

1. As part of the communication process within media relations, the involvement of PR specialists in maintaining contacts and building relationships must be greater than the commitment of journalists. This results from a weaker belief of the journalist environment in the necessity of mutual cooperation, as well as from a conscious need to strive for a good relationship, expressed by experts in the field of PR.

2. The initiative to establish contacts must be on the side of PR managers who should make sure these contacts are regular. They must also provide journalists with the information which is interesting for them, and, the need of a mutual contact should result from the relevance of the information provided.

3. PR specialists should contact journalists especially if they have to forward messages about crises in the company they represent, its new products and services, organized ventures that are of interest to journalists, and personnel changes in the company, because these problems are the most interesting from the point of view of the representatives of mass media.

4. PR managers should maintain contact with journalists, mainly through the instruments that are the most convenient and desirable from the point of view of the latter, i.e. e-mail, mobile phone and landline.

5. An important element of the expectations the journalists have of PR professionals is that they should use modern forms of contact, which are more convenient than traditional instruments, and allow journalists to save time (e.g. on-line press conferences).

6. Press releases and ready information on a specific subject should be basic materials prepared by PR-managers for journalists. Other elements in the system of informing media should complement them.

7. PR-managers should keep in mind that journalists expect from them mainly such materials that are free from advertising messages. In addition, they must be complete, accurate in terms of the content and must contain appealing information.

8. In the opinion of surveyed journalists a PR specialist should basically be: available, reliable, professional, honest and quick to react.

9. From the point of view of journalists, PR managers don't need to have a diploma in public relations, although it is advisable that they have graduated from human studies. 
10. Press conferences should be organized whenever there is a topic of interest for invited journalists. The conferences should be lead with a good pace and with the use of well-prepared materials. It is pointless to convene a conference if its purpose is of little importance. Too long duration and boring subjects are the main characteristics indicated by journalists as part of a badly-prepared press conference.

11. Information materials, prepared by PR specialists for journalists, cannot have an advertising character, they should not be too long, but ought to be interesting and written in a clear language.

12. PR-managers should constantly upgrade their skills connected with their appearance in the media and cooperation with them as it is shown by the survey of journalists who claim that the preparation of PR professionals in this field is poor.

13. The defects which PR-managers should eliminate from their relations with journalists include mainly exaggerated tendency to advertising and to activities connected with surreptitious advertising. In addition, PR managers should respect the time limits of journalists with whom they cooperate, and must try to understand their needs. They cannot be pushy when dealing with the media or exert pressure on journalists to prepare a publication.

14. Since corruption activities within the media relations are often born on the side of the PR environment, its representatives should adhere to ethical codes of conduct, developed by PR organizations and associations. They should neither provoke the situations where journalists are being forced to publish, omit or change the content of the message, nor should they offer journalists gifts or gratuities as the boundary between friendliness, promotion and corruption is quite subtle and cannot be clearly spotted.

A similar model of conditions concerning the expected behavior of journalists can be derived from the opinions expressed by the surveyed PR professionals. However, according to this model we cannot talk about the model of a journalist corresponding to the requirements of PR managers, but rather of a professional journalist, with whom not only specialists in PR would like to work, but also representatives of all other professions cooperating with the environment of journalism, including ordinary people - media recipients. The model of a professional journalist in relations with representatives of public relations should include the following elements [Gawroński, 2005, p. 281-282]:

1. In media relations professional journalists should, in the opinion of PR professionals, be interested primarily in new products and services offered by companies, their successes and projects realized by them. However, this is only the expectation of PR professionals, who are interested, from the point of view of their own interests, in precisely such behavior. Yet, encouraging journalists to tackle such issues stands in contradiction with the essence of the independence of the media and freedom of their functioning. Lack of interest in this kind of subject results sometimes from the fear that journalists have of advertorial messages and of a loss of credibility in the eyes of consumers.

2. Public relations environment expects professional journalists to be characterized above all by honesty, objectivity, professionalism, credibility and truthfulness. These features, conditioning the professional exercise of a journalist's job, are most appreciated by those PR managers who cooperate with journalists. This requirement is not only justified by the expectations of the representatives of the public relations branch, but also by the factors which make a journalist's job professional.

3. In the field of media relations a journalist is expected to eliminate the following drawbacks: lack of honesty and objectivity, lack of professionalism and general knowledge gaps. According to PR professionals, journalists should not fear too much that the information they receive contains hidden, advertorial or purely advertising 
messages.

4. According to PR professionals it is appropriate that journalists try to understand the needs of PR managers and conditions of their work. They should therefore be aware of the fact that media relations are the most important sphere of PR tasks carried out by PR managers in Poland and these relations are regarded by them as the most important. It seems, however, that the understanding of each other's needs for both of these environments leaves much to be desired, and their representatives do not always treat each other as allies, but rather as enemies and competitors.

5. Professionalism in the journalist's work should be based largely on the respect of ethical principles which make it clear what behaviors are unacceptable in journalists' work in terms of the construction of media messages and sending them to recipients, and in the process of gathering information or in relations of journalists with the PR industry.

\section{Interactions today}

The aforementioned study carried out in $2015^{4}$ was directed primarily at looking for an answer to the question: what affects negatively the relations between journalists and PR managers? The results do not give a direct answer although a lot of conclusions can be drawn from the data collected. The reasons should be looked for both in the journalists' and PR professionals' environments but, for obvious reasons, the drawbacks indicated by journalists are far more important. The results of the study do not provide clear opinions on the efficiency of PR managers. On the one hand, the majority of journalists (62\%) positively evaluate the usefulness of the information received from PR people, on the other hand, the majority of them (63\%) say that the PR materials they receive do not meet their expectations. It is hard to explain this paradox, relying solely on the presented results of the survey. The correlation of these responses would allow at least partially to explain the contradictions arising in the opinions expressed by the respondents. The blame for any resulting inaccuracies should be also shifted to the methodology used and to the construction of the research tool. Asking for opinions on the usefulness of the content received from PR-managers is simply too vague and needs developing a general evaluation. Meanwhile, most journalists probably receive in their professional life both useful and useless information from PR people. How to make an unambiguous judgment against this diversity?

The attempts to seek information on what hinders the relationship between journalists and PR industry can be looked for in the previous studies. Although most of them were carried out a dozen, or at least a few years ago, some of them seem to be true today, as they relate more to personal characteristics and labor standards, slowly changing in time, than to the tool sphere, within which a real revolution has been made in recent years. The negative personality traits of PR people are mainly: lack of competence, professionalism, impudence, insufficient factual knowledge, as well as the ignorance of the specifics of the functioning of the media and the ignorance of the expectations of journalists. Negative opinions on the materials received from PR managers usually refer to their exaggerated advertising character, incompleteness, exaggerated volume and hermetic language that hinders both understanding of the message and a journalist's work with the text.

The authors of Prowly research ask some interesting questions that actually arise from the results thereof. For some of them there are no obvious answers although they produce some assumptions.

$4 \quad$ The figures come from the report: E. Kowal (ed.), Od informacji do interakcji. O użyteczności informacji prasowych w relacji PR-owiec - dziennikarz, Prowly, Warsaw 2016, ebook.prowly.com (dated 24 April 2016). 
- As the survey revealed, most journalists maintain close relationships with a limited group (maximum 5) of PR managers. Similarly, most PR people reduce regular direct contacts to a small group of journalists. Is it then the maximum number of people in a circle of good professional relationships? It seems that the situation is normal and easily explainable. While most people select from a narrower or wider circle of people they know a preferred and privileged handful of those who can be described as friends, journalists and PR-managers act in much the same way within professional relationships. This is probably due to a certain identity of interests, or maybe similar businesses, but essentially it certainly depends on personality traits.

- Almost half (45\%) of journalists are not able to determine whether the information from PR people is visually appealing to them. What does it depend on? Perhaps it depends mostly on vagueness of the question asked. It might be difficult to find a common positive or negative assessment of different materials received by journalists from PR specialists. Most likely they are given both attractive materials and as well as those that do not meet their expectations.

- Half of the PR people do not ask journalists about the feedback, which coincides with the opinion of the journalists on this subject. May this phenomenon have an impact on mutual relations and understanding? Probably yes, although I would ascribe the reluctance of PR-managers to ask journalists for feedback to protecting themselves and avoiding suspicion of trying to force publication or exert other pressure. Experience shows that it is precisely in this area where there are many pitfalls affecting the mutual perception of both groups.

- The majority of journalists (75\%) said that PR people do not ask them about their interests and needs before publishing press releases. At the same time, most PR-managers (69\%) say that they do it. Similarly - most journalists claim that PR people send them information which does not comply with their interests, while $84 \%$ of PR people say that they classify both their contacts and information to be sent. How to explain these discrepancies which make it impossible to describe and understand the real situation? From a methodological point of view, it is difficult to confront the opinions of journalists based on their subjective judgment of their relationship with PR people, with declarative opinions of PR people, whose interest is to choose an appropriate response. A much more important thing in understanding these differences is the assumption (based both on personal observations and the studies available) that the environment of PR people has high self-esteem, regardless of the facts and of the verifiers of these opinions - journalists. Comparing the opinions of PR environment representatives about themselves with those expressed by journalists leaves no doubt that the PR industry in Poland is characterized by exaggerated self-esteem and exaggerated opinion of the importance of the work they do for journalists.

\section{Summary}

Standardization of cooperation between journalists and PR specialists is an extremely interesting issue from the point of view of the description of model realization of the fundamental spheres of tasks for PR, which are media relations. Despite the fact that public relations activity is difficult to fit within any schemes, standards or models, or even it should be characterized by departing from routine scenarios, attempts to describe a model of cooperation in the framework of media relations seem to be justified. Media relations are an extremely delicate part of PR activities, as they are carried out at the junction of two worlds and two highly individualized environments - journalism and public relations. As shown by the experience and observation of several years of the history of public relations in Poland, one of the key issues remains a high risk of conflict in the contact of both of these environments, other problems include continuous misunderstanding of each other's needs and low ethical value of mutual relationships. From this point of view, attempts to define the expectations of journalists from PR spe- 
cialists as well as the requirements of PR managers from journalists, and confronting them with each other, seems to be particularly justified.

\section{References}

DOBEK-OSTROWSKA B., BARCZYSZYN P., MICHEL A. (2013), Zmiana w dziennikarstwie. Kultura zawodowa polskich dziennikarzy (badania ilościowe), [in:] „Studia Medioznawcze”, n. 1(52), pp. 11-28.

DUDEK K. (2015), Rola rzeczników prasowych w komunikacji masowej, OW Humanitas, Sosnowiec-Praga. GAJDKA K. (2012), Rzecznik prasowy w otoczeniu mediów. Teoria i praktyka, Universitas, Kraków.

GAWROŃSKI S. (2005), Media relations. Współpraca komunikacyjna dziennikarzy i specjalistów PR, WSliz, Rzeszów.

KOWAL E.(ed.) (2016), Od informacji do interakcji. 0 użyteczności informacji prasowych w relacji PR-owiecdziennikarz, Prowly, Warsaw, ebook.prowly.com (24.04.2016).

SZCZEPANIK R., KRZYŻANOWSKA 0. (2003), Nietypowe przypadki public relations, OnePress, Gliwice. 